\title{
Clonal variation of wood density record of cambium reaction to water deficit in Picea abies (L.) Karst
}

\author{
Philippe Rozenberg*, Julien Van Loo, Bjorn Hannrup and Michael Grabner \\ INRA Orléans, Unité d'Amélioration, Génétique et Physiologie Forestières, BP 20619, Ardon 45166 Olivet Cedex, France
}

(Received 16 August 2001; accepted 6 February 2002)

\begin{abstract}
Water deficit during the growing season affects cambium activity; a water deficit during the first part of the growing season results in the formation of latewood-like cells. If this event is followed by a return to favourable water conditions, a microdensity profile drawn radially through the ring will reveal a density peak in the earlywood. This study proves that some characteristics of the peak formed in the earlywood of the ring 1993 in the trees of a Swedish Norway spruce clonal test ( 2 sites, 20 clones) are genetically controlled. The peak position in the ring is the most genetically controlled peak characteristic. The observed variability for the peak position in the ring can be related with an hypothesis concerning the presence of some degree of genetic control of the kinetic of the cambium reaction to environmental variation.
\end{abstract}

genetics / microdensity / water deficit / Norway spruce

Résumé - Variabilité clonale de la réaction du cambium à un déficit en eau chez Picea abies (L.) Karst. Un déficit en eau en cours de saison de végétation affecte l'activité du cambium ; si le déficit se produit en première partie de saison de végétation, on observe dans le bois initial du cerne formé cette année-là des cellules de type « bois final ». Si le déficit en eau est suivi d'un retour à des conditions favorables, un profil microdensitométrique tracé dans ce cerne révèle alors un pic de densité dans le bois initial. Cette étude met en évidence l'existence d'un contrôle génétique des caractères de ce pic de densité pour le cerne formé en 1993 chez les arbres d'un test clonal suédois ( 2 sites, 20 clones). Le caractère du pic le plus fortement contrôlé génétiquement est la position du pic dans le cerne. La variabilité ainsi observée de la position du pic dans le cerne peut s'expliquer grâce à l'hypothèse de l'existence d'un certain contrôle génétique de la cinétique de la réaction du cambium aux variations de l'environnement.

génétique / microdensité / déficit en eau / épicéa commun

\section{INTRODUCTION}

Breeding for adaptation is generally the first and most important goal of forest tree improvement programs. Adapted trees are trees that are physiologically suited for high survival, good growth and resistance to pests and adverse environments [35]. In order to select for adapted trees, it is necessary for the tree breeder to be able to estimate genetic variability of the tree response to pest and unfavourable conditions.

In case of adverse environment, survival and growth are affected. The product of tree growth is wood. Wood formation is a complex process initiated in the cambium. Under temperate climates, this process is periodic. Cells originating from the cambium during one growing season design a ring. The cell anatomical characteristics are very different according to their date of formation: for softwoods, wood produced at the beginning of the growing season (earlywood) is made of cells with thin walls and large lumen. Wood produced at the end of the growing season (latewood) is made of thick-wall, small lumen cells [15]. These differences have been shown to be a direct consequence of the global environmental change during the growing season [28]. Photoperiod $[5,14,16]$ and climate $[18,19]$ influence cambium activity, and thus wood formation and wood basic properties. Nature of the soil also influences wood formation $[1,9,32]$.

* Correspondence and reprints

Tel.: 02384178 73; fax: 02384178 79; e-mail: philippe.rozenberg@ orleans.inra.fr 


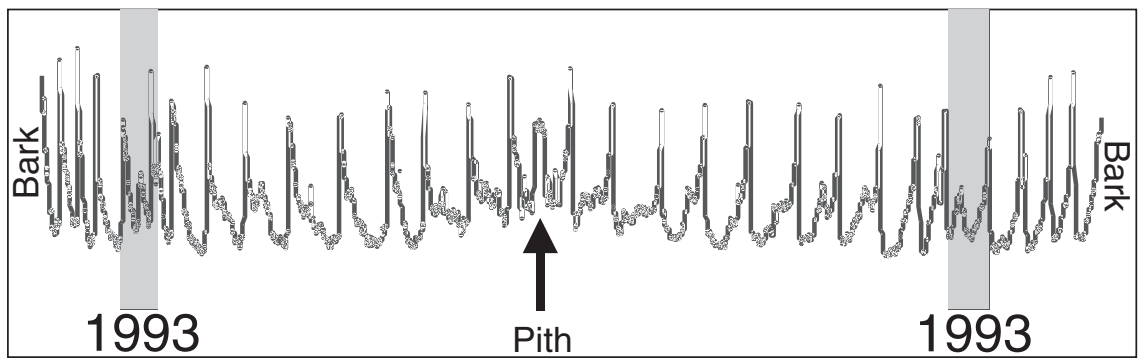

Figure 1. X-ray density profile of sample number 2 . The density peak in the earlywood of ring 1993 can be seen.

Water availability during the growing season is one of the main constraints for tree growth $[4,32]$. It can influence the characteristics of the ring formed during the same growing season, and during the next growing season [32]. Earlywood is wider for trees well irrigated, while it is narrower for trees submitted to drought (experiments on Pinus resinosa, [31], and Pinus sylvestris, [22]. For different softwood species, a water deficit during the first part of the growing season results in the formation of latewood-like cells. If this event is followed by a return to favourable water conditions, the cambium will form again earlywood-like cells [30]. A microdensity profile [20] drawn radially through this ring will reveal a density peak in the earlywood [6]. If the maximum density of this peak is close to the maximum density of the latewood, this feature is known as a "false ring" [11, 17, 24]. The density peak in the earlywood can thus be understood as a record of the cambium reaction to a water deficit $[6,31]$. Such a density peak was observed in the earlywood of most Norway spruce trees from a two-sites clonal test in southern Sweden (figure 1). At the same time, a close examination of the rainfall during year 1985 to year 1997 revealed a rainfall deficit during late 1992 and early 1993 (figure 2). Hence it seems reasonable to relate the density peak in the earlywood of ring 1993 to the water deficit in 1992-1993.

The objectives of this study are:

- to study the influence of the water deficit in 1992 and 1993 on some anatomy and microdensity characteristics of the Norway spruce wood samples;

- to study the site and the clonal variation of some variables describing the characteristics of the density peak in the earlywood of ring 1993;

- to discuss the consequences of the study results on the Norway spruce breeding program, and especially on the selection for adaptation to water deficit.

\section{MATERIALS AND METHODS}

\subsection{Plant material}

The samples of the study were collected on felled trees in 1998 in a single-tree plot clonal test established at two sites (Hermanstorp and Knutstorp) with very similar climates in southern Sweden in

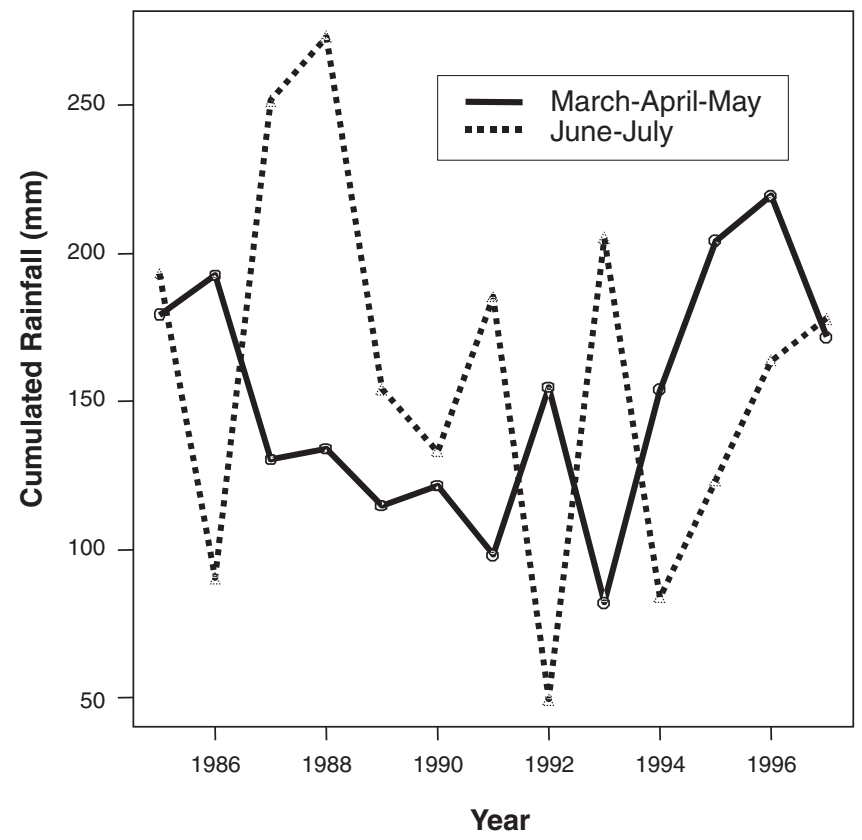

Figure 2. Cumulated rainfall during March-April-June and June-July in southern Sweden (data from Swedish National Meteorological Service). A relative deficit can be seen in 1992 (June-July) and in 1993 (March-April-March).

1978, in the frame of European Union Research Project Geniality (FAIR CT95 0909). At Hermanstorp 182 cuttings from 43 clones were selected, and 125 cuttings from 30 clones were selected at Knutstorp; 20 clones were common to both tests. The 307 trees were 19 -year-old at the time of the sampling. Detailed information about the tests and the sampling is available in [2].

The samples (discs cut at $1.5 \mathrm{~m}$ in the stem) were distributed among the partners of the European project Geniality [2].

\subsection{Variables and data analysis}

- Partner BOKU, Austria, observed wood anatomy. Discs were sanded and crossdated. The anatomy of the wood was observed microscopically. Among the wood anatomy traits observed, number and density of resin ducts in each ring, and number of cracks within rings were used in this study [8]. 


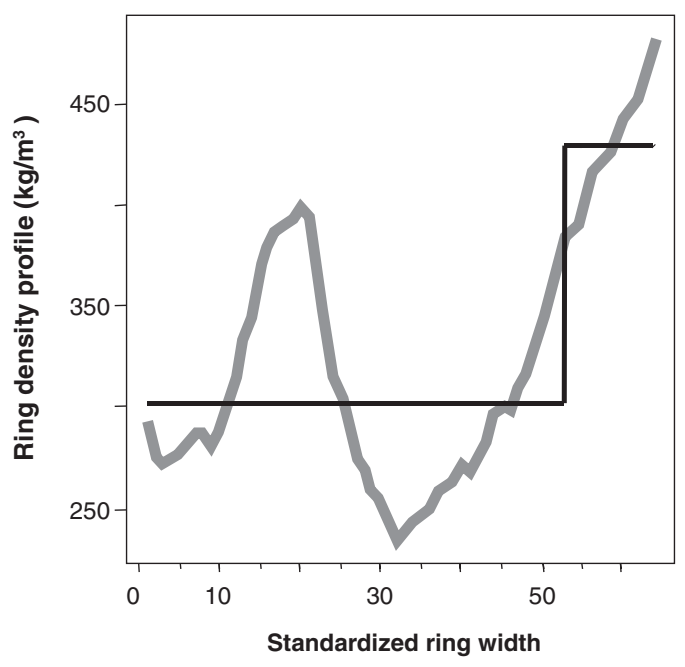

Figure 3. The earlywood - latewood model and the ring 1993: the earlywood latewood model is not adapted to ring 1993.

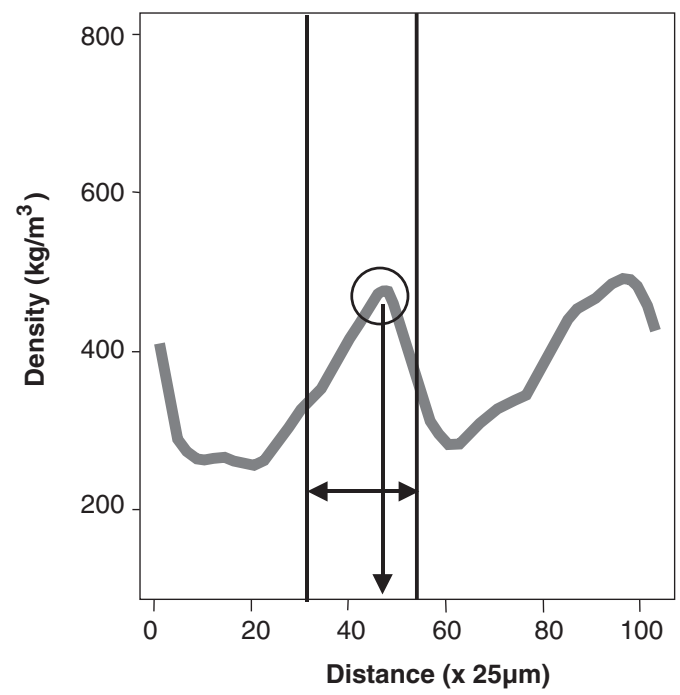

Figure 4. The figure describes the method used to compute the peak characteristics: the vertical bars are the peak boundaries, and defines "peak width". These boundaries are located at the position of the peak inflexion points. "Maximum peak density" is circled. The vertical arrow shows "peak position" in the ring (relative peak position in the ring). "Peak proportion" is "peak width" divided by "ring width".

- Partner INRA, France, recorded indirect X-ray microdensity profiles, following the method by Polge [20], and computed the within-ring density variables according to the earlywood-latewood (ew-lw) model [23]. A density peak was observed in the earlywood section of the 1993 ring density profiles in most trees of the clonal trial (figure 1). The ew-lw model is obviously not adapted to the description of the characteristics of this density peak (figure 3). Hence we developed an automatic procedure in order to compute simple characteristics of the density peak (figure 4). Correlation were computed among the set of peak variables, and some peak variables were discarded from the study because they were strongly correlated with other peak variables $(r>0.95, P<0.001)$. Four variables were used for the analysis of the genetic variation of the peak characteristics: peak maximum density, peak position in the ring, peak width and peak proportion (peak width divided by ring width) (figure 4).

- Anatomy and microdensity were observed in adjacent samples.

- Partner Sokgforsk, Sweden, computed the genetic parameters for the study variables.

Estimation of site and genotype variation and interaction for the peak characteristics was performed using the following analysis of variance model:

$$
\mathrm{Y}_{\mathrm{ijk}}=\mu+\mathrm{S}_{\mathrm{i}}+\mathrm{C}_{\mathrm{j}}+\mathrm{S} \cdot \mathrm{C}_{\mathrm{ij}}+\varepsilon_{\mathrm{ijk}}
$$

where $Y_{i j k}$ is the peak trait, $\mu$ is the general mean, $S_{i}$ is the site effect (fixed), $\mathrm{C}_{\mathrm{j}}$ the clone effect (fixed because only the 20 clones that are common to both sites are used in this analysis) and $\varepsilon_{\mathrm{ijk}}$ is the residual effect. Splus software [27] was used to perform that analysis.

The following mixed model was used in the calculation of the broad sense heritability (H2) of the two clonal trials:

$$
\mathrm{Y}_{\mathrm{ijk}}=\mu+\mathrm{B}_{\mathrm{i}}+\mathrm{C}_{\mathrm{j}}+\varepsilon_{\mathrm{ijk}}
$$

where $Y_{i j k}$ is the peak trait, $\mu$ is the general mean, $B_{i}$ is the block effect (fixed), $C_{j}$ the clone effect (random, because all clones available in each site are used in the analysis) and $\varepsilon_{\mathrm{ijk}}$ is the residual effect.

Variances were estimated with the ASREML software (Gilmour et al., 1999) and the heritability calculated as:

$$
H 2=\frac{\sigma_{c}^{2}}{\sigma_{c}^{2}+\sigma_{e}^{2}}
$$

where $H 2$ is broad sense heritability, $\sigma^{2}$ is the genotypic variance (clonal variance) and $\sigma_{e}^{2}$ is residual variance.

Genetic correlations were calculated as $\hat{r}_{g}=\frac{\hat{\sigma}_{G_{1} G_{2}}}{\hat{\sigma}_{G_{1}} \hat{\sigma}_{G_{2}}}$ where $\hat{\sigma}_{G_{1} G_{2}}$ is the genotypic covariance between characters.

Estimates of the standard errors of the genetic parameters were calculated from a Taylor series approximation as performed in the ASReml software [10].

\section{RESULTS AND DISCUSSION}

\subsection{Reaction to 1992 and 1993 water deficit}

Figure 5 presents the number and density of resin ducts per ring from 1985 to 1997 . The year 1993 displays the lowest resin ducts number and the lowest resin ducts density of the study chronology. Figure 6 shows the number of cracks per tree from 1985 to 1997 . The number of cracks is much higher in ring 1991 than in any other ring. According to Grabner et al. [8], these cracks were probably formed during 1992 and are a result of a water deficit during the middle and last part of the 1992 growing season (figure 2).

Figure 7 shows the development against physical year (between 1985 and 1997) of latewood mean density. Ring maximum density and ring density contrast (ring maximum density minus ring minimum density) develop the same type of pattern as latewood density. For each of these 3 microdensity variables, the observed value is minimum in 1993. 

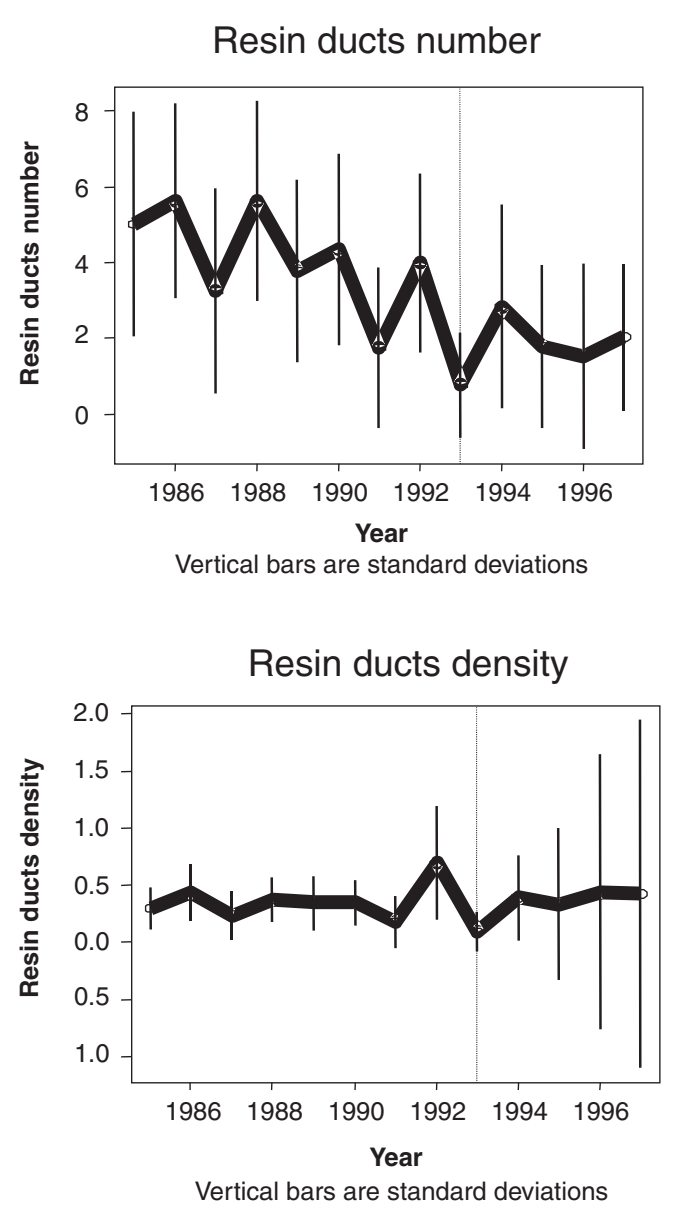

Figure 5. Resin ducts number and resin ducts density, observed on the 20 clones in the 2 sites, show their minimum value in 1993 .

As presented in the introduction, microdensity profiles of most trees of both clonal trial Hermanstorp and Knutstorp present a density peak located in the earlywood of ring 1993 (figure 1).

Hence trees in the clonal trial reacted to the 1992 and 1993 water deficit. The reaction could be observed especially in the ring 1993 itself, through a number of anatomy and microdensity variables, and in the ring 1991 (cracks). All the wood variables observed here can be understood as different ways to describe the tree reaction to a water deficit. In order to study the genetic variation of that tree reaction to the water deficit, we decided to focus our attention on the variables describing the characteristics of the density peak in the earlywood of ring 1993.

Results about relationships between, on one hand, peak characteristics, and, on the other hand, ring width and ring density, were published in [26]: while peak width and peak density were respectively nearly always significantly correlated with ring width and ring density (quite strongly in

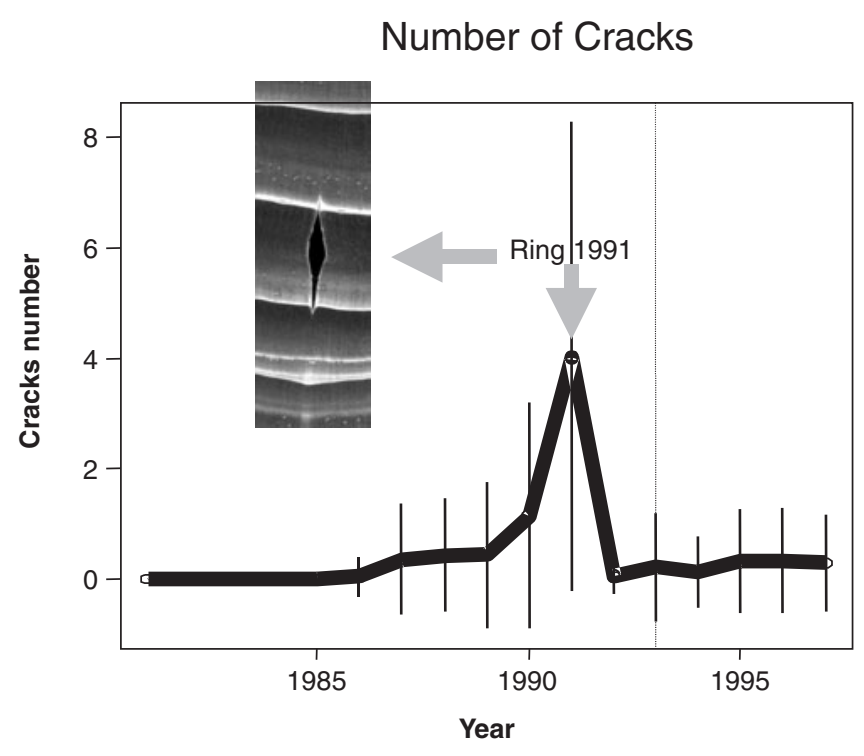

Vertical bars are standard deviations

Figure 6. the number of ring cracks observed on the 20 clones in the 2 sites reaches a maximum in 1991 . The X-ray picture shows a crack in ring 1991.

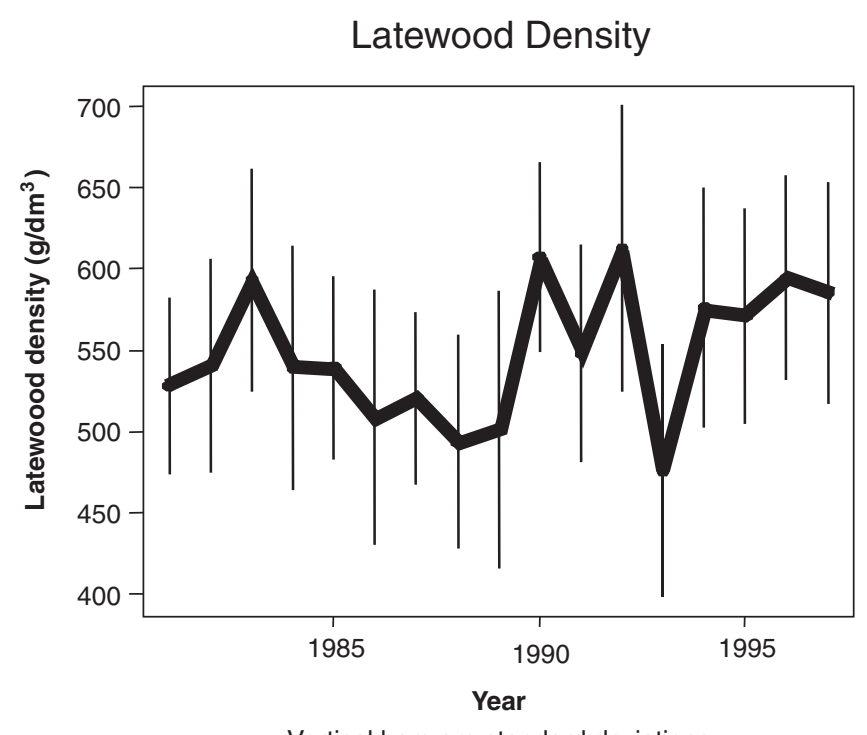

Figure 7. Latewood density (observed on 20 clones in the 2 sites) is minimum in 1993. Other microdensity variables showing a minimum in 1993 are maximum ring density and ring density contrast.

Knutstorp, from 0.41 to 0.95 ; and weakly in Hermanstorp, from 0.07 to 0.21 ), no relationship was found between peak position in the ring and neither ring width or ring density in any of the two sites. 


\subsection{Genetic and site effect on observed ring 1993 characteristics}

Table I shows the results of the fixed effect analysis of variance conducted on the peak variables.

There is a highly significant clone effect on all the peak characteristics. The most variable characteristic is the peak location (table I). This trait is also extremely variable between sites (table I). There is mostly no site effect for the other peak characteristics, and mostly no strong or not significant site-clone interaction for any peak characteristic.

\subsubsection{Site effect on peak location}

The peak formed during the growing season 1993 is probably related with the water deficit during March, April and May 1993 and in late 1992. The peak position in the ring is significantly different between sites. Both sites are located in the same climatic zone (south Sweden). Plant material (clones) and sylviculture (plantation density and thinnings) are the same in both sites (Karlsson, personal communication). The only big difference we found between both sites is the nature of the soil: Knutstorp soil is clay, while Hermanstorp soil is sand (Karlsson, personal communica-

Table I. Results of the fixed effect analysis of variance (F value and associated probability).

\begin{tabular}{lllll}
\hline $\begin{array}{l}\text { F } \\
\text { Probability) }\end{array}$ & $\begin{array}{l}\text { Peak Maximum } \\
\text { Density }\end{array}$ & $\begin{array}{l}\text { Peak } \\
\text { Position }\end{array}$ & $\begin{array}{l}\text { Peak } \\
\text { Width }\end{array}$ & $\begin{array}{l}\text { Peak } \\
\text { Proportion }\end{array}$ \\
\hline Clone & 4.89 & 7.34 & 3.94 & 3.22 \\
DF 19 & $\left(<10^{-8}\right)$ & $\left(<10^{-8}\right)$ & $\left(<10^{-8}\right)$ & $\left(<10^{-8}\right)$ \\
Site & 0.90 & 215.45 & 3.21 & 4.34 \\
DF 1 & $(0.344)$ & $\left(<10^{-8}\right)$ & $(0.074)$ & $(0.038)$ \\
Site.Clone & 1.86 & 0.87 & 1.42 & 1.13 \\
DF 19 & $(0.018)$ & $(0.625)$ & $(0.114)$ & $(0.319)$ \\
\hline
\end{tabular}

tion). There is no doubt that water availability is very different between clay and sand soils: after a rainfall, water is available much longer in clay soils than in sandy soils. In other words, water deficit appears earlier in sandy soils than in clay soils, and lasts more. Thus we conclude that the between-site difference for the nature of the soil is related with the between-site difference for the peak position.

Hence tree reaction in Hermanstorp can be considered as a reaction to a longer and thus more severe water deficit than in Knutstorp. At Hermanstorp the density peak is located at $49 \%$ of the ring width, while it is at $34 \%$ in Knutstorp (figure 8 ). Hence a peak located at $49 \%$ of the ring width would be a signal sent by a tree which is more stressed than when the peak is located before in the ring: position of the peak could be understood as a marker of the intensity of the stress endured by the tree.

\subsubsection{Clone effect on peak location}

The clone effect on the peak position is the strongest genetic effect for a peak parameter. The extreme values are $31 \%$ (minimum, clone 27343) and 53\% (maximum, clone 2816, figure 9). For clone 2816, the density peak is nearly completely merged with the latewood. Peak position in ring 1993 is nearly independent from the other peak characteristics (table II).

\subsubsection{Heritabilities and genetic correlation of the peak variables}

Results are presented in table II.

Estimation of genetic correlation was not very accurate (standard error of estimation is often over 0.3), especially in Hermanstorp. Estimations of heritability and phenotypic correlation were more accurate (standard error of estimation generally under 0.1 in both trials). The peak variable with the

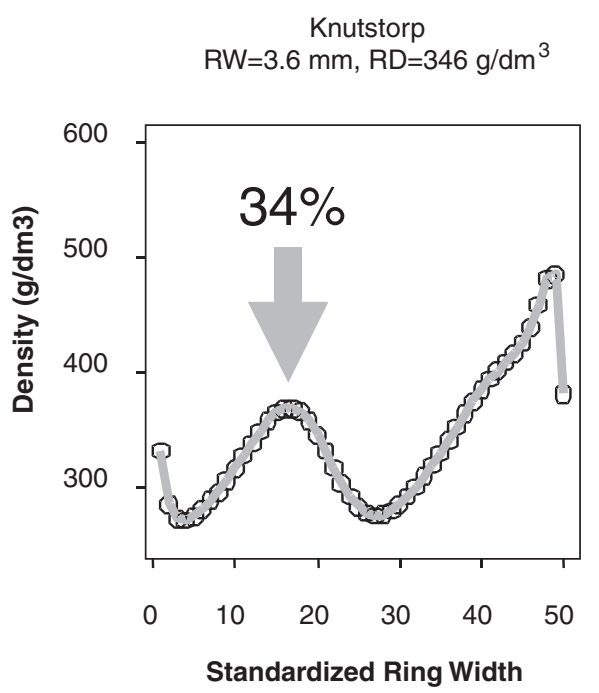

Standardized Ring Width

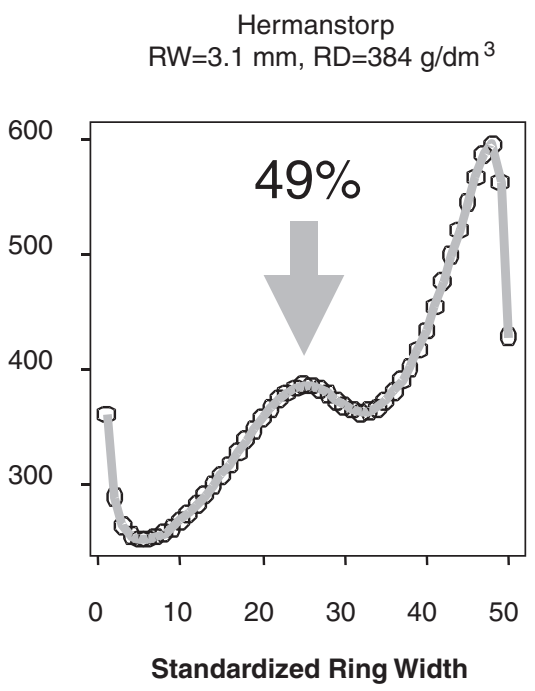

Figure 8. Mean density profiles of ring 1993 in Knutstorp and Hermanstorp; the density peak in ring 1993 is located much earlier in the ring in Knutstorp than in Hermanstorp. 
highest heritability is, in both sites, peak position (respectively 0.29 and 0.41 in Hermanstorp and Knutstorp). Peak width and peak proportion are strongly genetically and phenotypically related in Knutstorp. Only one of these two variables could be considered in future studies. Peak maximum density and peak width are also quite strongly (genetically) and moderately (phenotypically) negatively correlated in Knutstorp. This result can be linked with the well known general adverse relationship between wood density and radial growth in spruce (reviewed for example in [23]).

\subsubsection{Heritabilities of the cracks and resin ducts variables}

Results are presented in table III.

Figure 5 shows that resin ducts number is minimum in ring 1993. Figure 6 shows that internal cracks number is much higher in ring 1991 than in any other ring. According to [8], these cracks are the result of the late 1992 drought. We add that early 1993 water deficit could be involved too. Thus it is interesting to estimate the amount of genetic control of these 2 traits, understood as markers of tree reaction to the water deficit. Table III presents the heritability of these 2 traits. It is very low -nearly 0 - for resin ducts and much higher for crack number: heritability reaches 0.37 in Knutstorp and overall 0.67 in Hermanstorp for crack number in ring 1991, understood as a consequence of late 1992 and early 1993 water deficit.

\subsection{Consequences for tree breeders}

One advantage of using density data rather than anatomy data to study the cambium reaction to water is that wood density is generally considered a good indicator of wood quality for various end uses [33]. According to [34], it is the most important single trait useful to study the genetic variation of wood quality. Hence the same comprehensive data can be used in order to breed Norway spruce for adaptive traits and for wood quality traits.

According to our results, the variables with the strongest environmental and genetic control are the peak location in the

Table II. Results of the random effect analysis of variance: heritabilities, genetic and phenotypic correlations for the peak variables in both sites Knutstorp and Hermanstorp. Diagonal: heritability $H 2$, broad sense (standard error of estimation). Lower triangle: genetic correlation (standard error of estimation). Upper triangle: phenotypic correlation (standard error of estimation).

\begin{tabular}{|c|c|c|c|c|}
\hline & $\begin{array}{l}\text { Peak maximum } \\
\text { density }\end{array}$ & $\begin{array}{l}\text { Peak } \\
\text { position }\end{array}$ & $\begin{array}{l}\text { Peak } \\
\text { width }\end{array}$ & $\begin{array}{l}\text { Peak } \\
\text { proportion }\end{array}$ \\
\hline \multicolumn{5}{|l|}{ Hermanstorp } \\
\hline $\begin{array}{l}\text { Peak maximum } \\
\text { density }\end{array}$ & $0.26(0.08)$ & $0.46(0.07)$ & $-0.53(0.06)$ & $-0.49(0.06)$ \\
\hline Peak position & $0.68(0.18)$ & $0.29(0.09)$ & $-0.27(0.08)$ & $-0.27(0.08)$ \\
\hline Peak width & $-0.76(0.15)$ & $-0.62(0.21)$ & $0.27(0.08)$ & $0.89(0.02)$ \\
\hline Peak proportion & $-0.88(0.24)$ & $-1(0.36)$ & $0.85(0.11)$ & $0.10(0.08)$ \\
\hline \multicolumn{5}{|l|}{ Knutstorp } \\
\hline $\begin{array}{l}\text { Peak maximum } \\
\text { density }\end{array}$ & $0.23(0.10)$ & $0.23(0.10)$ & $-0.42(0.08)$ & $-0.21(0.10)$ \\
\hline Peak position & $0.20(0.30)$ & $0.41(0.10)$ & $-0.02(0.10)$ & $-0.02(0.10)$ \\
\hline Peak width & $-0.52(0.41)$ & $-0.10(0.46)$ & $0.08(0.09)$ & $0.69(0.06)$ \\
\hline Peak proportion & $0.18(0.48)$ & $-0.58(0.41)$ & $-0.14(0.80)$ & $0.16(0.10)$ \\
\hline
\end{tabular}

Table III. Results of the random effect analysis of variance: heritabilities for the resin ducts and cracks variables in both sites Knutstorp and Hermanstorp. Heritability $H 2$, broad sense (standard error of estimation).

\section{$H 2$}

Hermanstorp

Resin Ducts $1993 \quad 0.06(0.07)$

Cracks 1991

$0.64(0.07)$

Knutstorp

Resin Ducts 1993

Cracks 1991

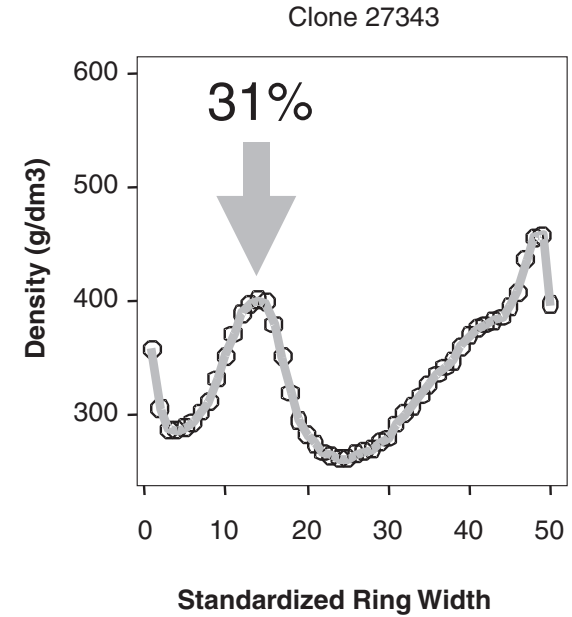

Standardized Ring Width

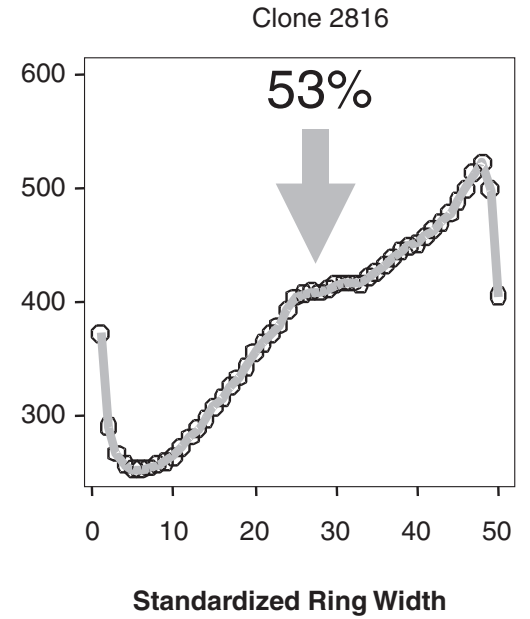

Standardized Ring Width
Figure 9. Ring 1993 density profiles of two extreme clones for the position of the density peak in the ring. The density peak is completely in the earlywood for clone 27343 , while it is nearly merged with the latewood in clone 2816. 
ring 1993 and the number of cracks in ring 1991. The heritabilities of these traits reach some respective values of 0.41 (peak position in Knutstorp) and 0.67 (crack number in Hermanstorp). Such values indicate that breeding for tree reaction to water deficit, using peak position in the ring, and/or number of cracks as markers of adaptive value, is possible. The absence of significant relationship between peak position and ring width or ring density indicates that (1) this reaction to water deficit is independent from radial growth and (2) indirect selection on adaptation to water deficit using peak position could be possible at no cost for ring width and ring density.

In that case, a very important question for the tree breeder is the following one: what is a favourable reaction to a water deficit? Is it to produce a ring with a peak located in the earlywood, or to produce a peak located closer to the latewood? The answer to this question is not straightforward. From the wood quality point of view, there is no doubt that internal cracks are a defect $[3,21]$, and that they should be avoided. But seeing crack number as a marker of tree adaptation to drought, the answer is not so clear. If we consider the site effect on peak position, one hypothesis could be that, for a given stress level, clones with a "late" peak are more stressed than clones with an "early" peak. Then the clones more adapted to a water deficit would be the clones with an early peak.

But the parallel drawn between the explanation of the site effect (clay soil-sand soil) and of the clone effect is not a proof, and hardly an hypothesis: another hypothesis could be that trees growing on sand are every year affected by water deficit, and thus grow roots very deep in the soil in order to find water. While trees growing on clay usually have water available near the surface in the soil, and do not grow roots very deep. Then these trees could be more severely affected by a rare water deficit.

Hence the information collected and analysed in this study does not seem sufficient to tell which reaction marks a better adaptation to water deficit.

In what way are latewood-like cells more adapted to water deficit than earlywood-like cells? A latewood-like cell is a cell with a narrow lumen and a thick wall. The narrow lumen decreases the risk of cavitation (in case of cavitation, the sap does not ascent anymore, and thus is not conducted to the leaves, [25]). According to recent results, the thick cell wall would prevent the risk of xylem implosion [12]. Hence an early cambium reaction to a water deficit, leading to the quick formation of latewood-like cells, would be a favourable adaptation. Is peak position in the cell related to the time of peak formation? Our data does not provide determinant information useful to answer that question.

Hence it seems now important to understand how variation for the peak location is related with variation in the time of formation of the peak during the growing season. Spatial measurements of wood density need to be converted to a time scale, rather than on a distance scale. Such conversion requires recording of high-resolution growth data. This can be done using either band dendrometers (for example [13]) or point dendrometers (for example [7, 29]). To our knowledge, such devices have never been used to record diameter growth on a genetically structured population.

Such measurements would provide the basic information useful to study the genetic variation of the time of the formation of the density peak, of the transition between earlywood and latewood, and of the beginning and of the end of the cambium activity.

This study lets expect possible use of simple wood density traits computed from X-ray density profiles to assess genetic variability of tree adaptation to some climate characteristics. Microdensity is widely used in tree breeding to simultaneously study the genetic variation of tree growth (diameter growth) and of wood quality (wood density). Results of this study demonstrate that it could be used, at least in some cases, to also study the genetic variation of tree adaptation to some aspects of climate. Is the same kind of study possible in other species than Norway spruce? Results by Zahner et al. ([31], on Pinus resinosa) and Polge et Keller ([22], on Pinus sylvestris) demonstrates than the same kind of reaction can be seen on these species. It would be very interesting to study the genetic variation of microdensity variables marking tree reaction to well identified stress episodes in different softwood species. Such analysis would permit long term a posteriori analysis of tree adaptation to important and adverse environmental variation.

\section{CONCLUSION}

Two wood traits related with 1992 and 1993 water deficit were found to be very variable and quite strongly or strongly genetically controlled: internal crack number and peak position.

According to [8], there is a strong evidence that extreme weather fluctuation, i.e. dry-wet cycles, may have resulted in high internal mechanical tension strains due to tangential shrinkage that have exceeded fracture limits of wood. Internal cracks are at the same time an important wood quality defect, and a genetically controlled marker of tree reaction to some water deficit.

The position in the ring of the density peak formed during the first part of the growing season 1993 is strongly variable.

The peak position is variable between sites. The difference between the 2 sites for the peak location is large, and very strongly significant. The difference between both sites for climate is very small, and can't explain the observed difference for the peak location. Oppositely, the soils of the 2 sites are very different: Knutstorp in mainly clay soil, while Hermanstrop is mainly sand soil. Since the nature of the soil strongly influences the water availability in the soil, the difference between the soils of the two sites may explain the difference observed between the two sites for the mean peak location. Further work is necessary in order to determine how 
such soil difference could explain the difference between sites for the peak location.

The peak position is also variable among clones. The clone effect for the peak location is strongly significant too. It is the strongest among the calculated peak characteristics. If we agree that the density peak is a reaction of the cambium to a water deficit during the first part of the growing season, then the observed clonal variation for the peak location can be interpreted as the existence of genetic variation of the tree reaction to a water deficit.

Synchronising the microdensity profile with time seems a promising way to better analyse the genetic and environmental control of wood formation.

Acknowledgement: Thanks to Frédéric Millier for the X-ray microdensitometry, and thanks to all the Geniality people for the great work and time!

\section{REFERENCES}

[1] Burczyk J., Giertych M., Response of Norway spruce annual increment to drought for various provenances and locations, Silvae Genet. 40 (1991) $146-152$.

[2] Cahalan C., "Genetic improvement of wood quality: increasing selection efficiency for different end-uses", FAIR CT98 3953 Progress Report 01.04.1998-31.03.1999, 53 p.

[3] Cherubini P., Schweingruber F.H., Forster T., Morphology and ecological significance of intra-annual radial cracks in living conifers, Trees 11 (1997) 216-222.

[4] Climent J., Gil L., Pardos J., Heartwood and sapwood development and its relationship to growth and environment in Pinus canariensis, For. Ecol. Manage. 59 (1993) 165-174.

[5] Denne M.P., Smith C.J., Daylength effects on growth, tracheid developpment and photosynthesis in seedlings of Picea sitchensis and Pinus sylvestris, J. Exp. Bot. 22 (1971) 347-361.

[6] Downes G., Evans R., Effects of environment on tracheid dimensions, CSIRO Division of Forest Products, Victoria, Australia, 1994.

[7] Downes G., Beadle C., Worledge D., Daily stem growth patterns in irrigated Eucalyptus globulus and E. nitens in relation to climate, Trees 14 (1999) $102-111$.

[8] Grabner M., Gierlinger B., Wimmer R., Mechanism leading to intra-ring radial cracks in young spruce trees, summary in proceedings "Tree Rings and People. An International Conference on the future of Dendrochronology", September 22-26, 2001, Davos, Switzerland.

[9] Granier A., Badeau V., Bréda N., Modélisation du bilan hydrique des peuplements forestiers, Rev. For. Fr. XLVII (1995) 59-68.

[10] Gilmour A.R., Cullis B.R., Welham S.J., Thompson R., ASREML Reference Manual, Orange, Australia, $210 \mathrm{p}$.

[11] Glerum C., Drought ring formation in conifers, Forest Sci. 16 (1970) 246-248.

[12] Hacke U.G., Sperry J.S., Pockman W.T., Davis S.D., McCulloh K.A., Trends in wood density and structure are linked to prevention of xylem implosion by negative pressure, Oecologia 126 (2001) 457-461.

[13] Hincley T.M., Bruckerhoff D.N., The effect of drought on water relations and stem shrinkage of Quercus alba, Can. J. Bot. 53 (1975) 62-72.
[14] Jenkins P.A., Hellmers H., Edge E.A., Rook D.A., Burdon R.D., Influence of photoperiod on growth and wood formation in Pinus radiata, $\mathrm{N}$. Z. J. For. Sci. 7 (1977) 172-191.

[15] Ladefoged K., The periodicity of wood formation, Kgl. Danske Vidensk. Selsk. Biol. Skr. 7 (1952) 1-98.

[16] Larson P.R., The indirect effect of photoperiod on tracheid diameter in Pinus resinosa, Am. J. Bot. 49 (1962) 132-137.

[17] Larson P.R., The indirect effect of drought on tracheid diameter in Red pine, Forest Sci. 9 (1963) 52-62.

[18] Lebourgeois F., Climatic signals in earlywood, latewood and total ring width of Corsican pine from western France, Ann. For. Sci. 57 (2000) $155-164$

[19] Nicholls J.W.P., Warring H.D., The effect of environmental factors on wood characteristics. IV. Irrigation and partial droughting of Pinus radiata, Silvae Genet. 26 (1977) 107-111.

[20] Polge H., Établissement des courbes de variations de la densité du bois par exploration densitométrique de radiographies d'échantillons prélevés à la tarière sur des arbres vivants. Application dans les domaines technologiques et physiologiques, Thèse de doctorat, Université de Nancy, 1966, 206 p.

[21] Polge H., Nouvelles observations sur les fissures radiales du Douglas, Rev. Forest. Fr. 6 (1984) 453-458.

[22] Polge H., Keller R., Influence de l'approvisionnement en eau sur la structure interne des accroissements annuels ; expérience d'irrigation sur des Pins sylvestres, Ann. Sci. For. 25 (1968) 125-133.

[23] Rozenberg P., Cahalan C., Spruce and wood quality: genetic aspects (a review), Silvae Genet. 46 (1997) 270-279.

[24] Shepherd K.R., Some observations on the effect of drought on the growth of Pinus radiata D. Don, Aust. For. 28 (1964) 7-22.

[25] Sperry J.S., Limitations on stem water transport and their consequences, in Plant stems, physiology and functional morphology, in: Gartner B.L. (Ed.), Academic Press Inc., 1995.

[26] Van Loo J., Effet climatique et clonal sur l'enregistrement microdensitométrique du fonctionnement du cambium chez l'épicéa commun (Picea abies (L.) Karst), Rapport de DEA, Université Henri Poincaré Nancy I, UAGPF INRA Orléans, 2000, 19 p.

[27] Statistical Sciences, S-PLUS Guide to Statistical and Mathematical analysis, Version 3.4, Seattle, StatSci, a division of MathSoft, Inc., 1996.

[28] Wilkes J., Interpreting patterns of variation in tracheid morphology in Pinus species, Commonw. For. Rev. 66 (1987) 177-190.

[29] Wimmer R., Downes G.M., Evans R., High-resolution analysis of radial growth and wood density in Eucalyptus nitens, grown under different irrigation regimes, Ann. For. Sci. 59 (2002) 519-524.

[30] Zahner R., Internal moisture stress and wood formation in conifers, Forest Prod. J. 13 (1963) 240-247.

[31] Zahner R., Lotan J.E., Baughman W.D., Earlywood - latewood features of red pine grown under simulated drought and irrigation, Forest Sci. 10 (1964) 361-370.

[32] Zahner R., Water deficits and growth of trees, in: Water deficits and plant growth, 3 volumes, Kozlowski T.T. (Ed.), Academic Press, New York, 1968, pp. 191-254.

[33] Zobel B.J., Van Buijtenen J.P., Wood variation: Its causes and control, Springer-Verlag, Berlin, 1989, 363 p.

[34] Zobel B.J., Jett B.J., Genetics of wood production, Springer-Verlag, Berlin, 1995, $337 \mathrm{p}$.

[35] Zobel B.J., Talbert J.T., Applied forest tree improvement, John Wiley's \& Sons, Inc., New York, 1984, 505 p. 